\title{
$-60^{\circ} \mathrm{C}$ に小ける共析鋼の疲労を裂の進展挙動*
}

（を裂先端部におけるすべり線の発生加ら

き裂の発生・進展に至る疲労過程)

\author{
高 \\ 行 \\ 男** \\ Behavior of Fatigue Cracks in Plain Specimens \\ of Eutectoid Steel at $-60^{\circ} \mathrm{C}$ \\ (Fatigue Process from Slip Initiation to Crack Propagation at Crack Tips)
}

by

\section{Haeng-Nam Ko}

(Nakanihon Automotive College, Gifu)

The behavior of fatigue cracks in plain specimens of eutectoid steel subjected to macroscopic tensile and shear stresses was examined by cyclic torsion tests at $-60^{\circ} \mathrm{C}$. The results obtained were compared with those at room temperature. The critical propagating stress of the fatigue crack was higher at $-60^{\circ} \mathrm{C}$ than at room temperature for the same crack length. At the critical propagating stress, however, the size of slipped region at the crack tip and micro-Vickers hardness measured at room temperature in this region were little affected by both the crack length and the difference in fatigue test temperature. The hardness value in this region was smaller in the specimen subjected to tensile stress than to shear stress. The fatigue process from slip initiation to crack propagation at a crack tip was affected by the test temperature, the stress mode generated at the tip and the existence of the hardened layer at the tip.

(Received Dec. 7, 1981)

キー・ワード：共析鋼, 疲労き裂, すべり線

\section{1 緒言}

材料に発生した疲労き裂の進展は, 先端部に拉ける 繰返しすべりが重要な役割を果しているので, 著者ら はき裂先端部のすべり線発生領域に着目し, 常温にお けるき裂の進展挙動をその先端部に作用する応力の状 態と材料の疲労強度との相互関係に基ついて検討して きた。

ところで，き裂先端部のすべり形成の難易はき裂の 進展限界応力と密接に関係し, 雾囲気温度がすべり形 成に影響を及ぼす要因の一つとなっている，したがっ て, 試験温度とき裂の進展挙動の関連をき裂先端部に 発生するすべり線領域に着目して検討することは合理 的な方法と考えられるが，常温以外，特に低温下に和 いて詳細に検討した研究報告は数少いようである.

以上の観点から，本報告ではまず低温に和けるき裂 の進展挙動に検討を加えることを目的としたが，この

* 原稿受理 昭和 56 年 12 月 7 日

** 正 会員 中日本自動車短期大学 波阜県加茂郡坂祝町深盍
際，き裂の進展に影響を及ぼす因子の一つであるひず 又時効の抑制を行らため, 疲労試験温度として $-60^{\circ} \mathrm{C}$ を選んだ.

引張形およびせん断形さ裂を有する共析鋼丸棒平滑 材に繰返しねじりを加え，き裂先端部におけるすべり 線の発生状態を詳細に観察し, き裂長さとすべり線発 生限界応力および進展限界応力との関係をすず求めた。 ついで, き裂進展限界応力に和いて先端部に発生する すべり線領域内のかたさを測定し, 常温における結果 と比較してごのかたさに及ぼすき裂先端部の応力状態 およびひずみ時効の抑制効果の影響について検討した. さらに,き裂先端部に拈いて繰返し応力の上昇に伴っ て進行するすべり線の発生からき裂の進展に至る疲労 過程が試験温度和よびき裂の負荷形式の相違によって 異ることを指摘した.

\section{2 実験装置および方法}

\section{$2 \cdot 1$ 試験片および試験機}

供試素材は従来の報告で使用したものと同じ SK-5 
の引抜き丸棒で, その化学成分を Table I に, 機械 的性質拈よび熱処理条件を Table II に示す. 試験片 はFig. 1 に示すような形状に加工した後, 中央の平 行部分は紙やすりで \#320 まで仕上げ，加工硬化層を 除去するため， $640^{\circ} \mathrm{C} ， 1$ 時間の真空焼なましる行っ てから，電解研摩によって鏡面仕上げを施した。この 際, 微小ビッカースかたさ計 $(25 \mathrm{~g})$ 厹用いてかたさ を測定し, 硬化層の除去に対する確認を行った。試験 機は, 回転曲げには小野式疲労試験機, 繰返しねじり にはシェンク式疲労試験機（ともに $3600 \mathrm{rpm}$ ) を使 用した。

Table I. Chemical composition (\%).

\begin{tabular}{c|c|c|c|c}
\hline $\mathrm{C}$ & $\mathrm{Si}$ & $\mathrm{Mn}$ & $\mathrm{P}$ & $\mathrm{S}$ \\
\hline 0.85 & 0.19 & 0.36 & 0.019 & 0.007 \\
\hline
\end{tabular}

Table II. Mechanical properties and heat treatment.

\begin{tabular}{ll|c|c}
\hline & & $\begin{array}{l}\text { Room tem- } \\
\text { perature }\end{array}$ & $-60^{\circ} \mathrm{C}$ \\
\hline Upper yield point & $\left(\mathrm{kg} / \mathrm{mm}^{2}\right)$ & 32.4 & 39.3 \\
Lower yield point & $\left(\mathrm{kg} / \mathrm{mm}^{2}\right)$ & 30.8 & 37.4 \\
Tensile strength & $\left(\mathrm{kg} / \mathrm{mm}^{2}\right)$ & 63.5 & 73.9 \\
Elongation & $(\%)$ & 25.6 & 25 \\
Reduction of area & $(\%)$ & 40 & 37 \\
\hline Heat treatment & & $\begin{array}{l}\text { Annealing at } 800^{\circ} \mathrm{C} \\
\text { for one hour }\end{array}$ \\
\hline
\end{tabular}

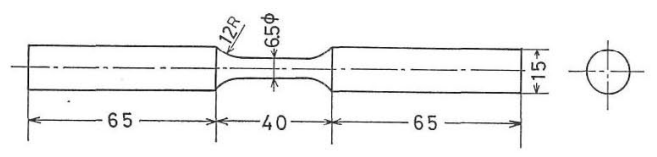

(a) Rotary bending-cyclic torsion.

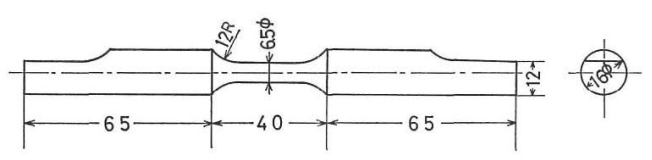

(b) Cyclic torsion.

Fig. 1. Fatigue test specimens.

\section{$2 \cdot 2$ 冷却装置}

試験片の冷却には冷媒として液体空素のガス化した ものを用い，これをエポキシ樹脂のブロックを加工し て製作した冷却そう内薄くことによって, 所定の低 温雲囲気を作った．試験片の温度は表面に取付けたア ルメル・クロメル熱電対によって検出し, 温度変動を 最大土 $2^{\circ} \mathrm{C} に$ 执さえた。

\section{$2 \cdot 3$ 実験方法}

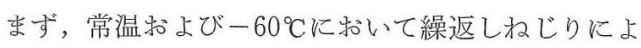
る平滑材の $S-N$ 曲線学求め, 疲労限度を定めるとと
もに, 繰返し数 $N=(0.5 \sim 1) \times 10^{7}$ に和けるすべり線 発生限界応力を求めた。 また, Fig. 1 に示した試験片 に対して常温に和いて回転曲げ执よび繰返しねじりの 疲労限度よりもわずかに高い応力を適当な繰返し数に 加え, 予き裂の作製を行った後, 電解研摩によってこ の試験片表面を数 $\mu \mathrm{m}$ 除去し, $640^{\circ} \mathrm{C}, 1$ 時間の真空 焼なましを施して, 疲労による硬化層を除去した試験 片（き裂材）を製作した。このき裂材に対して常温抒 よびー60゚特いて繰返しねじり試験を実施し，き裂 長さと進展限界応力特よびすべり線発生限界応力との 関係を求めた。

\section{3 実験結果および考察}

\section{$3 \cdot 1$ 疲学限度およびすべり線発生限界応力}

常温执よびー $60^{\circ} \mathrm{C}$ に拈ける疲労限度は, それぞれ $\left(\tau_{w}\right)_{\text {R.T. }}=16.0 \mathrm{~kg} / \mathrm{mm}^{2}, \quad\left(\tau_{w}\right)_{\text {L.T. }}=20.5 \mathrm{~kg} / \mathrm{mm}^{2} \tau ゙$ あったまた，平滑材のすべり線発生限界応力 $\tau_{s o}$ と しては，400 倍の光学顕微鏡で観察してすべり線が確 認できる場合を基準に取ったが, 繰返し数 $N=(0.5 〜$ 1) $\times 10^{7}$ に対してそれぞれ $\left(\tau_{\text {so }}\right)_{\text {R.T. }}=10.0 \mathrm{~kg} / \mathrm{mm}^{2}$, $\left(\tau_{\text {so }}\right)_{\text {L.T. }}=16.0 \mathrm{~kg} / \mathrm{mm}^{2}$ となった.

\section{$3 \cdot 2$ き裂長さと進展限界応力}

供試素材では, 疲労限度よりわずかに高い応力の繰 返しによって発生した予き裂は，Fig. 2 に示すように， 回転曲げでは試験片の軸にほぼ垂直方向, 繰返しねじ りでは軸にほぼ $45^{\circ}$ 方向に存在している。したがって， それぞれのき裂材に繰返しねじりを加えれば，後者の 場合はき裂の進展方向が主応力に直角方向を取るので， 進展に寄与与るき裂先端部の応力は巨視的に引張応力 となる(引張形き裂)。また，前者の場合には，き裂 先端部は巨視的にせん断応力る受けることになる（せ え断形裂).

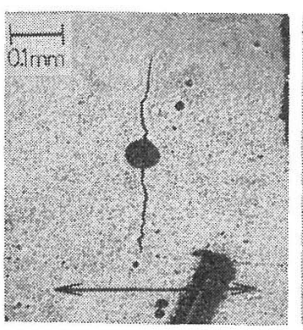

(a) Rotary bending.

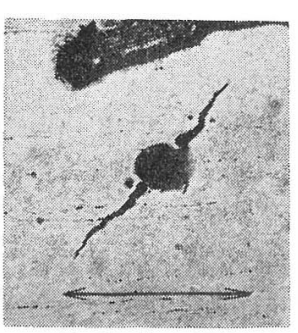

(b) Cyclic torsion.
Fig. 2. Examples of precracks. (Arrow indicates the specimen axis.)

このような引張形およびせん断形き裂を有するき裂 材に対して繰返しねじりを加壳，N=1×107 の時点で き裂進展の有無を調查し, 常温おょびー $60^{\circ} \mathrm{C}$ に水いて き裂長さ $l$ と進展限界応力 $\tau_{e}$ の関係を求めた結果を Fig. 3 に示す。図の縦軸の進展応力七としては, き裂 が存在しないときの公称応力を取った. き裂進展の有 


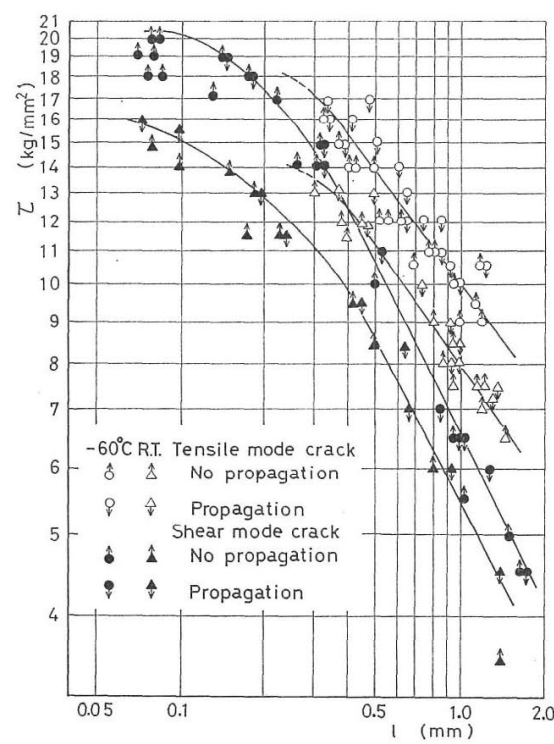

Fig. 3. Relation between the propagating stress and the crack length.

無の判定は, 先端部のすベり带を 1200 倍の火学顕微 鏡で観察し, その中に黒い筋が明白に確認できる場合 を基準とした。図から明らかなように，同一の $l$ に対 する $\tau_{c}$ は引張形扰よびせ九断形の両場合とも, -60 Cの場合の淘引が常温に执けるよりも高いが，き裂が 長くなるにつ狆てこの差は次第に小さくなる傾向にあ る・すなおち, き裂長さの增加に伴ら $\tau_{c}$ の低下割合 は, $-60{ }^{\circ} \mathrm{C}$ のほらが常温の場合より大きくなり， た, 平滑材の疲労限度 $\tau_{w}$ の $\tau_{c}$ に対する比 $\tau_{w} / \tau_{c}$ はー60゚のほうが常温に比べて高くなる. 切欠さ材で は，温度の低下に伴ら痚学限度の上昇割合が平滑材の それに比べて小さく, 低温では切欠き係数が大きくな ることが報告されているが，この傾向はき裂材に対し ても認められることが確認された。

\section{$3 \cdot 3$ き裂先端部のすべり領域}

$N=(0.5 \sim 1) \times 10^{7}$ に選び，き裂先端部に発生する すべり領域の有無を調査して, き裂長さ $l$ とすべり線 発生限界応力 $\tau_{s}$ との関係を求め玌ば Fig. 4 の上ら になる、ただし，縦軸のすべり発生の応力てとては， き裂が存在しないときの公称応力を取った。ずベり発 生の有無の判定は, 400 倍の光学顕微鏡で観察し, 先 端部の約 $0.01 \mathrm{~mm}$ 以上の領域にすべり線の発生があ る場合をすべりありと判定した。図から明らかなっら にー $60^{\circ} \mathrm{C}$ 常温の結果を比較すると, 同一のlに対す るてsは引張形执よびせん断形き裂の両場合とも 60

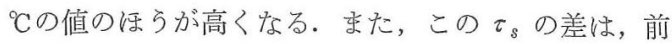
述の $\tau_{c}$ の場合と同様に，き裂が長くなるにつれて次 第に小さくなっていくので，lの増加に伴う $\tau_{s}$ の低 下割合は， $-60^{\circ} \mathrm{C} の$ 㭱らが常温の場合より大きくな

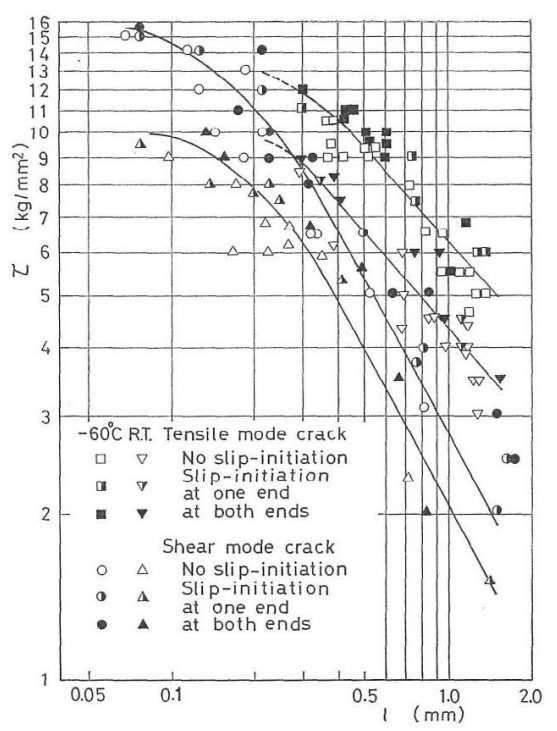

Fig. 4. Relation between the slip-initiation stress and the crack length.

る. Fig. 3，4 比較すると，各試験温度に扮いてl の増加に伴ら $\tau_{s}$ の低下割合は $\tau_{c}$ のそれに比べ高く なる傾向が認められる、本た，取扷ったき裂長さの範

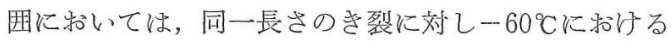
$\tau_{s}$ の常温に和ける矢れに対する比 $\left(\tau_{s}\right)_{\text {L.T. T. }} /\left(\tau_{s}\right)_{\text {R.T. }}$ は $\tau_{c}$ k関し同様に求めた $\left(\tau_{c}\right)_{\text {L.T. }} /\left(\tau_{c}\right)_{\text {R.T. }}$ より若干 大きくなり， $\tau_{s}$ に及ぼす低温の影響が $\tau_{c}$ のそれに 比べ大きくなることがわかった。

Fig. 5 には，試験温度一 $60^{\circ} \mathrm{C}$ 和いて繰返し応力の 上昇に伴うき裂先端部のすべり領域の増加状沉の一例 を示したが，この試験温度では常温の場合と同様に， き裂が進展するには先端部のある領域にわたってすべ

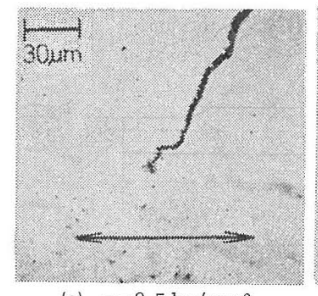

(a) $\tau=8.5 \mathrm{~kg} / \mathrm{mm}^{2}$

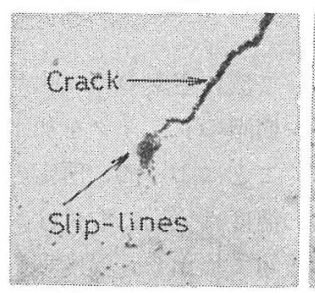

(c) $\tau=12.0 \mathrm{~kg} / \mathrm{mm}^{2}$

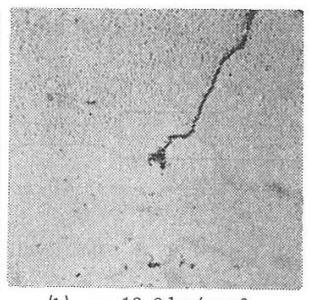

(b) $\tau=10.0 \mathrm{~kg} / \mathrm{mm}^{2}$

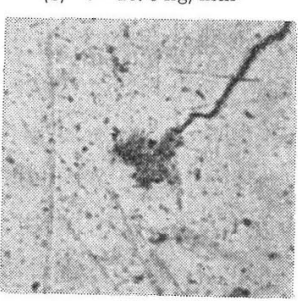

(d) $\tau=14.0 \mathrm{~kg} / \mathrm{mm}^{2}$
Fig. 5. Region of slip-lines at the crack tip with cyclic stress. $\left[-60^{\circ} \mathrm{C}, \quad l=0.48 \mathrm{~mm}, \quad\right.$ Tensile mode crack, $N=(0.5 \sim 1) \times 107]$ 
りが発生することが必要であることがわかる，そこで， -60年に和壮る進展限界でのすべり領域の大きさを常 温の場合と比較検討するため, き裂長さ $l$ と進展限界 応力 $\tau_{c}$ 近傍の応力によるすべり発生領域の大きさ $\xi$ との関係を求め，その結果を Fig. 6 亿示した。 $\xi$ の 值は，き裂先端からすべり発生領域の周緑までの最大 長さ（一般にはき裂の進展方向）を倍率 400 倍の顕微 鏡写真に基づいて測定したものである. 四から明らか なように，き裂進展限界（図で○との、 界）に括汀る $\xi\left(=\xi_{0}\right)$ は，本実験に抢沙るき裂長さの 範囲では，引張形およびせん断形き裂のいずれに対し ても長さ $l$ 亿関係なくほぼ一定で, $\xi_{0} \fallingdotseq 0.04 \mathrm{~mm}$ とな っており，またこの值は試験温度にほとんど依存しな いことがわかる。

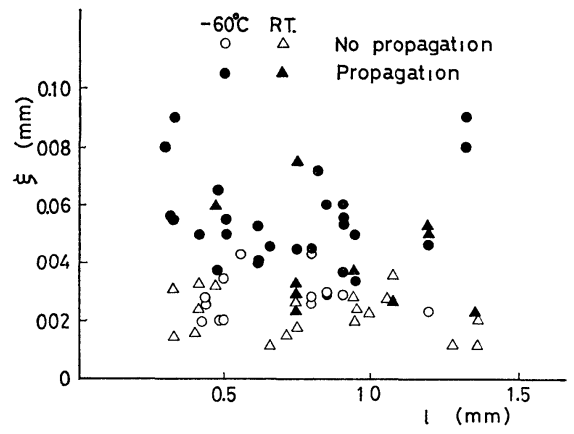

(a) Tensile mode crack.

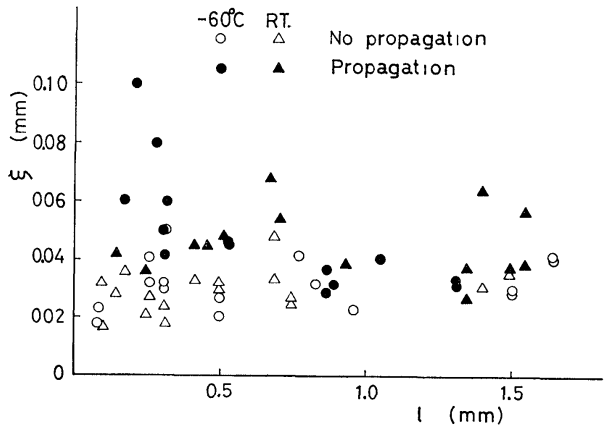

(b) Shear mode crack.

Fig. 6. Relation between the size of slipped region at the crack tip and the crack length at stresses near the critical propagating stress.

\section{$3 \cdot 4$ き裂先端部のかたさ変化}

ひずみ時効は巨視的には繰返し応力による加工硬化 現象として現れ，これはかたさ変化として認められる. そこで, 引張形およびせん断形き裂を有する試験片に 対してひずみ時効の抑制が考兄られるー $60^{\circ} \mathrm{C} て ゙$ 疲労試 験を行い, き裂の進展限界にお竹洗端部のかたさ変 化を調查して，常温の結果と比較検討した．かたさ試 験はすべて常温で行い, 微小ビッカースかたさ計（25 g）を使用したが，この際に生ずる圧こんはき裂先端
部のすべり領域内のかたさ（き裂先端部のかたさ）を 測定するのに充分であった。 また，すべり領域外のか たさには変化がなかった。

-60゚拈けるき裂の進展限界近傍の応力による先 端部のかたさとき裂長さとの関係を示せば，Fig. 7 の ようになる，図の右端には，進展あり，なしの各場合

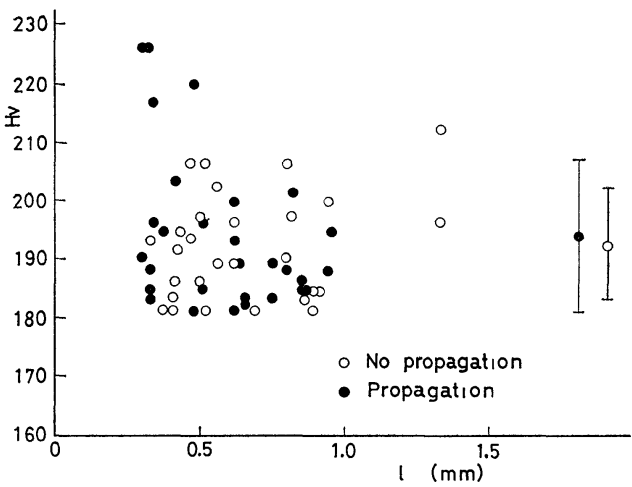

(a) Tens1le mode crack.

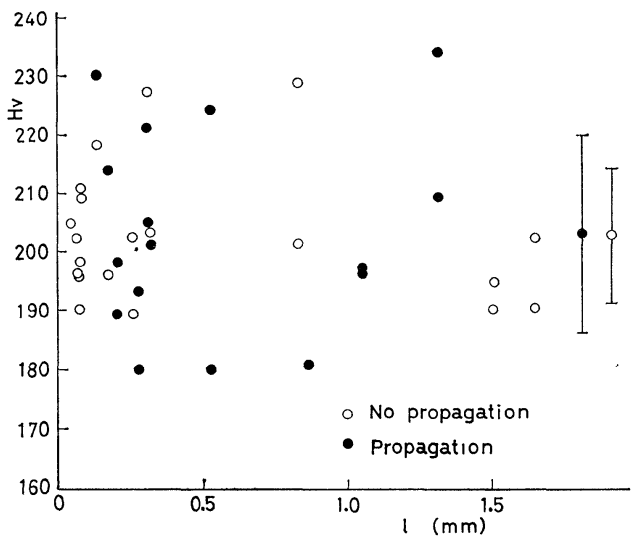

(b) Shear mode crack.

Fig. 7. Relation between the hardness at the crack tip and the crack length at stresses near the critical propagating stress.

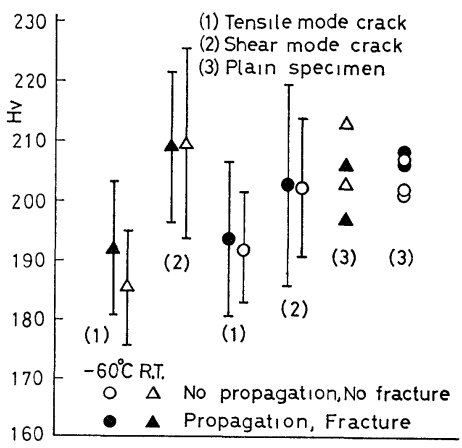

F1g. 8. The hardness at the crack tip at stresses near the critical propagating stress and average hardness of the plain specimen at stresses near the fatigue limit. 
に対するかたさの平均值および標準偏差を示した。 Fig. 8 は，同様な方法によって得られた常温の場合の 結果と本実験の結果を比較したものである、また，図 には常温抒よびー $60^{\circ} \mathrm{C}$ に和いて繰返しねじりに対する 疲労限度近傍の応力によって平滑材に生じたすべり領 域の 20 点の平均かたさを併記した。なお，処女材のか たさは $H_{V} \fallingdotseq 165$ であった. Fig. 7, 8 から明らかな ように, $-60^{\circ} \mathrm{C}$ に拈いても常温の場合と同様に, 引張 形き裂はせん断形き裂に比べて進展限界でのかたさが 低く, 先端部で繰返される応力の相違による差異が認 められる。 また, 各試験温度に拈いて絽返しねじりに よる平滑材の疲労限度でのかたさがせん断形き裂の進 展限界に拈けるかたさと対応しており，せん断形き裂 の進展に際しては, 先端部の材料が繰返しねじりによ る平滑材の疲労限度に相当する材質の変化（かたさ変 化）を受ける必要があると考觉られる．したがって， ひずみ時効の抑制効果はき裂先端部と平滑材に対して 顕著に相違しないものと考兄られ, き裂進展限界に和 けるき裂先端部と疲労限度に括汗平滑材の両場合に 沶いて塑性変形に伴って起るひずみ時効の効果は, ほ ぼ同程度であると推察される.

\section{$3 \cdot 5$ き裂先端部におけるすべり発生からき裂の発 生・進展に至る過程}

各き裂長さに対してすべり線発生限界応力 $\tau_{s}$ (Fig. 4）とき裂進展限界応力 $\tau_{c}$ (Fig. 3) から次の值 $\phi=$ $\left(\tau_{c}-\tau_{s}\right) / \tau_{c}$ を求め, 常温执よび $-60^{\circ} \mathrm{C}$ に拈いて $\phi$ と $l$ との関係を示せば，Fig.9のよらになる.ただし実 線で示したせん断形き裂材の場合には, 前節で述べた ように, き裂進展限界での先端部には平滑材が疲労限 度 $\tau_{w}$ を受けたとさと同程度の材質の変化が生じてい ると考光られるので, $l=0$ に拈ける中の值（図中の 印）は平滑材の疲労限度ならびにすべり線発生限界応 力を使用して求めた.

図から明らかなよらに，同一き裂長さに対する中の

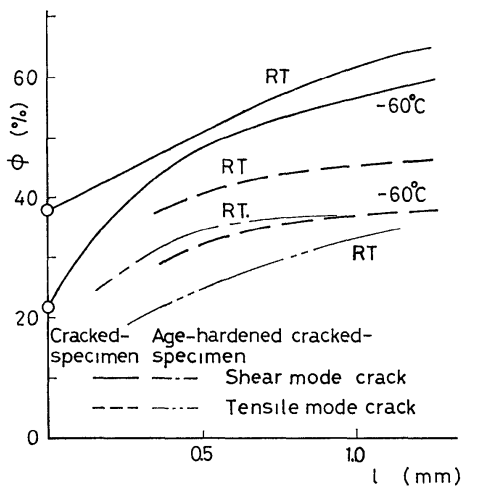

Fig. 9. $\phi$ due to test temperature, stress mode generated at the crack tip and existence of the hardened layer at the tip.
值は，き裂先端部の負荷形式にかかわらず常温のほう が高くなる. この材料の下降伏点 $\sigma_{y}$ と引張強さ $\sigma_{B}$ (Table II) に基づいて $\phi^{\prime}=\left(\sigma_{B}-\sigma_{y}\right) / \sigma_{B}$ を算出すれ ば, 一 $60{ }^{\circ} \mathrm{C}$ に和ける $\phi^{\prime}$ は常温のそれよりも小さくな る. このことは, 切欠さ強度を静荷重によって検討し た報告にも認められ， $\phi^{\prime}$ は上述の $\phi$ 同様な傾向を 示している. 雾团気温度が低下すると $\phi^{\prime}$ の值が小さ くなるのは, 温度の低下に伴う $\sigma_{y}$ の上昇の度合に比 べて降伏後の加工硬化による材料強度の増加割合が, 低温になるにつれて少くなることを意味している.す なわち, 繰返し荷重を受けるき裂材においても, 雾囲 気温度の低下に伴いき裂先端部にすべり線が発生し始 める応力値 $\tau_{s}$ 抒よび進展開始に必要な応力值 $\tau_{c}$ は ともに上昇するが，き裂先端部にすべり線が発生し繰 返乙応力の上昇に伴ってその領域が増加してき裂の進 展が始まるまでの過程は，-60 Cのほうが常温よりも 容易であることを申の結果は意味しており，材料の静 的強度の温度依存性がき裂材のき裂進展開始に至るま での瘦労挙動の温度依存性に反映されている.なお, 図に捈いて申值がき裂が長くなるにつれて高くなって いるのは, $3 \cdot \mathbf{3}$ 節で述べたように, き裂長さの増加 に伴う $\tau_{s}$ の低下割合が $\tau_{c}$ のそれより大きくなるた めである.

Fig. 9 から明らかなように，同一長さのき裂に対し て引張形き裂に拈ける申值は, 各試験温度に拈いてせ 几断形き裂の々れに比べて低くなるが，き裂の進展限 界に拾ける先端部のすべり発生領域の長さには両形の き裂に扣いて顕著な差がなかった [Fig. 6 (a)，(b)]. すなわち, き裂先端部におけるすべりの発生からさ裂 の進展に至る過程の難易は引張応力の大きさに支配さ れ，その応力值が大きいほどすべりの発生からき裂の 進展に移行する過程が容易であるため, 上述の結果が もたらされたものといえる.

ところで, фは材料の静的強度と密接に関連してい るので，き裂先端部に硬化層が存在するか否かによっ て影響を受けるものと考えられる，そこで，予き裂を 作製した後，焼なましを行らかわりに $200{ }^{\circ} \mathrm{Cで} 1$ 時間 の時効硬化を施した時効き裂材に対し, 常温に拈いて $3 \cdot 2,3 \cdot 3$ 節と同様の試験を行い $\tau_{s}-l$ 扰よび $\tau_{c}-l$ の関係を求めた. その結果を Fig. 10 に示す. この結 果に基づいて $\phi$ 值と $l$ との関係を求め, それを Fig. 9 に併記した．時効き裂材の $\tau_{c}, \tau_{s}$ は焼なまされた場 合 (Fig. 3，4）に比べそれぞれ高くなるが，Fig. 9 よ り申值は低くなることがわかる，すなわち，き裂先端 部に予め硬化層が存在している場合には, 焼なまされ た状態に比べて，すべり線の発生からき裂の進展への 移行過程が先端部にすべり線が発生するまでの過程に 対して相対的に容易になるといえる. 


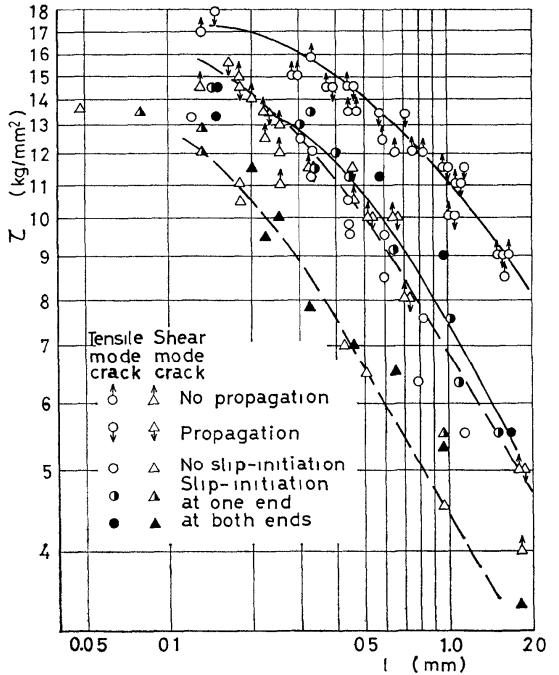

Fig. 10. The slip-initiation stress and the propagating stress for age-hardened crackedspecimen at room temperature.

\section{4 結言}

長さ $0.05 \sim 1.5 \mathrm{~mm}$ の範囲のき裂を有する共析鋼 平滑材に $-60^{\circ} \mathrm{C}$ の低温で繰返しねじりを加え，巨視的 に引張りまたはせん断を受けるき裂の挙動について調 查を行い, 常温に和いて得られた諸結果と比較検討し た結果, 次の結論が得られた。

（1）同一長さのき裂では， $-60^{\circ} \mathrm{C}$ に拈けるき裂進展 限界応力 $\left(\tau_{c}\right)_{\text {L.T. }}$ ならびにき裂先端部のすべり線発 生限界応力 $\left(\tau_{s}\right)_{\text {L.T. }}$ は常温 の場 合の值 $\left(\tau_{c}\right)_{\text {R.T. }}$, $\left(\tau_{s}\right)_{\text {R.T. }}$ に比べて高くなる. また，き裂長さの増加に 伴う $\tau_{s}, \tau_{c}$ の低下割合は $\tau_{s}$ のほうが $\tau_{c}$ に比べて 高くなり， $\tau_{s o} / \tau_{s}, \tau_{w} / \tau_{c}$ はそれぞれー $60{ }^{\circ} \mathrm{C}$ の汪らが 常温の場合より大きくなる.

(2) $\left(\tau_{s}\right)_{\text {L.T. }} /\left(\tau_{s}\right)_{\text {R.T. }}$ は $\left(\tau_{c}\right)_{\text {L.T. }} /\left(\tau_{c}\right)_{\text {R.T. }}$ より若干 大きくなり， $\tau_{s}$ に及ぼす低温の影響は $\tau_{c}$ のそれに比 べて大きい。

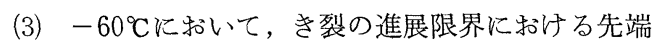
部のすべり発生領域の長さは, 常温の場合之同様に, き裂長さに関係なくほぼ一定であり，両場合において
その長さには顕著な差がなかった。

（4）上述のすべり領域内を常温中で測定したビッカ 一スかたさは, 引張形き裂のほうがせん断形き裂より も小さくなり，先端部が実際受ける負荷形式の影響が 認められる。また, 後者のかたさは疲労限度における 平滑材表面のすべり発生領域内のかたさと注涪同程度 である.

（5）ひずみ時効の抑制効果は，き裂の進展限界応力 に和ける先端部之疲労限度に括活る平滑材に扣いて顕 著に相違しないるのと考觉られる。

（6）き裂の先端部にすべりが発生し，繰返し応力の 上昇に伴ってその領域が増大してき裂の発生・進展に 至る過程は, 試験温度, 先端部が直接受ける負荷形式, 負荷前においてき裂先端部の材料に硬化層が存在する か否かによって相違する.

最後に, 本研究に対しご指導を賜わった名古屋大学 工学部, 清家政一郎教授叔よび北岡征一郎助教授に深 く感謝いたします。

（昭和56年11月10日 第15回疲労シンポシウムにて講演）

\section{参 考 文 献}

1）横堀武夫，日本機械学会誌，72，1216（1969）；74，4 (1971).

2) 宮本 博, 日本機械学会誌, 72, 176 (1969).

3）北岡征一郎, 高 行男, 日本機械学会論文集, 42, 1954 (1976).

4) 清家政一郎, 北岡征一郎, 高 行男, 日本機械学会論文 集, 42, 317 (1976).

5) 清家政一郎, 北岡征一郎, 高 行男, 日本機械学会論文 集, 41，1 (1975).

6) 清家政一郎, 北岡征一郎, 高 行男, 日本機械学会論文 集, 40, 1819 (1974).

7) 清家政一郎, 北岡征一郎, 高 行男, 日本機械学会論文 集，40，609 (1974).

8）たと兄ば，大内田 久, 安藤司文, 日本機械学会論文集, 30, 52 (1964).

9）荒木 透, “金属学会セミナーテキスト”, p. 52 (1964) 日本金属学会

10）前川一郎，日本機械学会論文集，39，1（1973）. 